\title{
ENGLISH FOR INFORMATICS ENGINEERING: NEEDS ANALYSIS
}

\author{
Sukma Septian Nasution ${ }^{1}$, Nur Najibah Sukmawati ${ }^{2}$, Lodya Sesriyani ${ }^{3}$ \\ ${ }^{123}$ Universitas Pamulang, Indonesia \\ dosen02032@unpam.ac.id
}

\begin{abstract}
English for Vocational School is a key to bridging non-English major students' needs including Informatics Engineering students of a private university in South Tangerang, Indonesia. Accordingly, it is important to conduct a needs-analysis study as a way to find the source of information to designing proper English materials. To actualize it, a set of questionnaire was distributed to 35 students of Informatics Engineering Study Program to investigate their necessities, lacks, and desire in learning English for vocational purpose. The data were analysed quantitatively to figure out majority choices to each item questioned. Semi-structured interview to both the lecturers and the students were also conducted to explore reasons for each finding. The result showed that the students were expected to be proficient at using English for daily communication which will be useful for their future working-community because most of the students thought that they were not fluent yet and found difficulties especially in grammar mastery. Accordingly, they expected that instructional process be directed to learning English related to Informatics Engineering without ignoring daily communication topics. These overall findings are a milestone to designing a set of English learning materials for the third semester students of Informatics Engineering Students of the university.
\end{abstract}

Keywords: needs analysis, english for specific purposes, informatics engineering

\section{BAHASA INGGRIS UNTUK TEKNIK INFORMATIKA: NEEDS ANALYSIS}

\begin{abstract}
ABSTRAK
Bahasa Inggris untuk pendidikan vokasi merupakan disiplin ilmu yang sangat tepat untuk memenuhi kebutuhan penguasaan bahasa Inggris di bidang tertentu seperti program studi Teknik Informatika di sebuah universitas swasta di Tangerang Selatan, Indonesia. Oleh karena itu, analisa kebutuhan mahasiswa terhadap pembelajaran bahasa Inggris dilaksanakan sebagai langkah awal dalam mengembangkan modul ajar. Teknik survey dengan menggunakan kuesioner diberikan kepada 35 mahasiswa Teknik Informatika untuk menemukan kepentingan (necessities), kekurangan (lacks), dan keinginan (desire) dalam belajar bahasa Inggris. Hasil kuesioner divalidasi dengan interview dosen pengampu mata kuliah serta beberapa mahasis wa. Secara umum, hasil penelitian menunjukkan bahwa kebutuhan belajar bahasa Inggris adalah untuk komunikasi dalam percakapan sehari-hari yang juga berguna untuk masa depan mahasiswa karena diketahui bahwa kebanyakan mahasiswa menemukan kesulitan terutama dalam menerapkan pengetahuan gramatika bahasa Inggris dalam percakapan. Modul ajar khusus teknik informatika dengan input keterampilan berbahasa menjadi masukan untuk mengembangkan bahan ajar bahasa Inggris untuk Teknik Informatika.
\end{abstract}

Kata Kunci: analisa kebutuhan, bahasa inggris untuk tujuan khusus, teknik informatika

\begin{tabular}{|c|c|c|}
\hline Submitted & Accepted & Published \\
\hline 30 Januari 2020 & 24 April 2020 & 21 Mei 2020 \\
\hline
\end{tabular}

\begin{tabular}{|l|c|l|l|}
\hline Citation & $:$ & Nasution, S.S., Sukmawati, N.N., \& Sesriyani, L. (2020). English For Informatics Engineering: Needs Analysis. Jurnal \\
\hline
\end{tabular} PAJAR (Pendidikan dan Pengajaran), 4(3), 478-488. DOI : http://dx.doi.org/10.33578/pjr.v4i2.7959.

\section{INTRODUCTION}

Developing proper materials for students to learn is significant in making instructional process a success and to survive in the Englihspeaking community (Richards, 2001). Accordingly, the development must have a strong basis that enlightens to what extent the materials are to be developed. The fashioned strategy to have such basis is called needs analysis. Needs analysis carries with it some kinds of assessment and evaluation of the latest condition used as the basis to diagnose deficiency that should be covered (Astika, 1999) to develop a curriculum (Plesca, 2018). Such activities were famous to many scholars in 1920 but were negligible until Richard and Rodgers brought it back for the rise of English for specific purpose (ESP). ESP gained 
its popularity in the beginning of the 21 st century where it takes English as a key of success to survive globalization. Universities respond this by including English as a compulsory subject with specific purposes characterized by its focus on selected topics relevant for a particular professional field, such as business, medicine, aviation, and tourism (Chovancov, 2018). Learning English is, consequently, aimed to no longer focus on language skills only (Nasution, and Sukmawati, 2019), or to help students pass exam but also to empower and brace them to the future vocational environment (Hattani, 2019). Accordingly, analyzing the students' needs to gain such target must be conducted deliberately.

Analyzing students' needs has been a reliable strategy as a starting point to develop materials. In the process of assessing the students' need, the ESP practitioner has to contribute their best to reveal information about the needs and wants of the learners, and the situational context where it takes place (Morrocan, 2019). It can be done by introducing them to texts, genres, discourses and communicative situations that they are likely to encounter in their professional lives as strategy to provide them a chance to practice some of the communicative skills, specific terminology and relevant issues typical of their fields (Chovancov, 2018). Practically, involving students and teachers in taking and providing information so that ideas from teachers and

\section{LITERATURE REVIEW}

Many researchers have conducted such study as Hashem Ahmed Alsamadani (2017) Analyzing needs analysis to Saudi Engineering Students, his study aims at identifying the learners' key requirements and determines the areas where they lack skills. Undertaken during the academic year of 2015-2016, the study that has been published in Advances in Language and Literary Studies Journal includes classroom observation protocol, questionnaire, and semi-structured interview to 200 students of civil and industrial engineering students. He comes to findings that reading and listening were mostly focused on in ESP classes though in fact writing and reading were the ones needed more than other language students can be more accommodated (Nunan, 2001). Since analyzing the students' needs in learning English is crystal important, this study aims at finding out the students' necessities, wants, and lacks in learning English for informatics engineering study program of a private university in South Tangerang, Indonesia.

To inquire information from the students, some strategies can be used. One of popular strategies is by survey techniques through questionnaire. Questionnaire is relatively easy to run even to a large number of subjects. It is also relatively easy to tabulate and analyze (Youngshin, Youn-Jung, Doonam, 2015). This instrument is also commonly used to find information about various types of linguistic necessities (Nimasari, 2018) language usage, communication difficulties, preferred learning styles, preferred classroom activities, and attitudes and beliefs (Indrasari, 2016).

This study is a preliminary step to designing English materials for the students' "Need" as "something that is recognized but it is not in any sense "discovered"' and its "existence" derives from whatever criteria are thought to be relevant in making the diagnoses," Lawson (1979) which are differentiated to the purpose of individual differences, learning the language, or the social roles of language in a wider context (Astika, 1999).

skills. His study is equally extended as ours to the extent to scrutinizing students' needs in learning English for specific purpose particularly in engineering context. However, if Alsamadani focuses on determining language tasks necessary for the students in the context of engineering studies, our study focuses on finding out the students' lacks, necessities, and wants to determine what learning activities are best given to the informatics engineering students.

Another study was conducted by Sri Diana and Musdalifah Mansur (2018). Thy aimed to find out English materials students of a genetic computer department of a private university in Makassar needs. Data collections were gathered by 
interviewing two English lecturers and distributing questionnaire to thirty sophomores through purposive sampling technique. The findings are (1) two language skills were necessarily needed. They are speaking skill and writing skill; (2) vocabulary and grammar are successively the most important language elements the students need to be proficient at English; (3) previously, language materials were not developed through needs analysis. This paper is related to ours in two terms: (1) needs analysis as the topic; (2) informatics engineering students as object of the study. However, items of the questionnaire put language skills as completely partial seen from the main finding. On the other hand, we managed to formulate our questionnaire from different perspective.

A need-analysis in ESP context was also conducted by Elok Putri Nimasari of Ponorogo
Muhammadiyah University. With quantitative approach, the study entitled An ESP Needs Analysis: Addressing the Needs of English for Informatics Engineering sees the analysis as fundamental indicators in developing ESP syllabus. To 95 students of the university, a set of questionnaires was distributed to find out the students' perception to why they need to learn English, when English is used, the use of English in the future. As the result, 10 areas of English materials are essential to develop. Whether English should be a compulsory subject, and so on. This study is nearly similar to ours by objectives and objects of the study. The difference is theoreticalbased that her study compares the findings to the one by Khan (2007) while our study has nothing to do with comparing the findings to any expert.

lecturer and meeting the students for eleven questions called open-ended interview. Their answers to choices of each item were converted to percentage to find out which choice is dominant over the other choices. The dominant choices were then considered as the most insightful input to be considered in developing English modules for the students. The formula is depicted by figure 1 . validate the findings from the questionnaire, each dominant answer is crosschecked to English

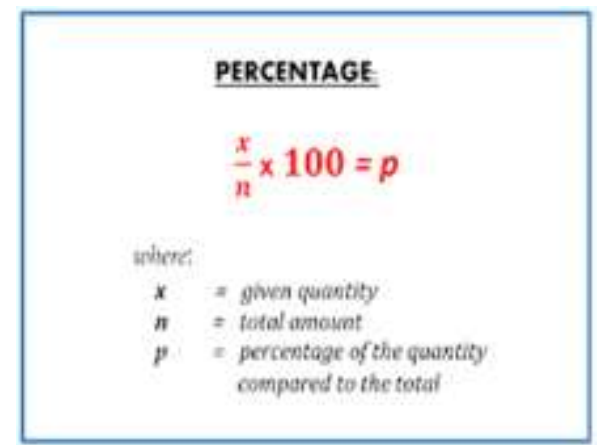

Figure 1. Formula to Finding Out The Percentage

This is a survey study contextualized to the students of Informatics Engineering Study Program of a private university, South Tangerang. 35 sophomores were chosen as the participants.
The sophomores were chosen because they were undertaking English subject that has not been designed based on needs analysis. They were given eleven questions related to their necessities, wants, 
and needs to learning English for Informatics Engineering Study Program.

\section{FINDING AND DISCUSSION}

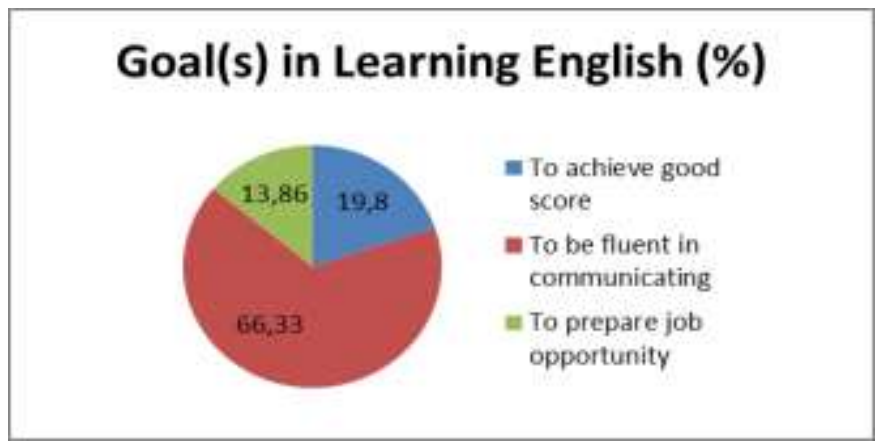

Figure 2. The Students' Goals in Learning English

Figure 2. shows that $66.33 \%$ of the total choices is addressed to the students learning English in order to be fluent in communication both in oral and written form. It reveals that language skills should remain the most important materials to be included. On the other hand, $19.8 \%$ of them learn English for just achieving good final score in English subject, and surprisingly, only $13.86 \%$ of them choose preparing job opportunity as a main reason to learn English.

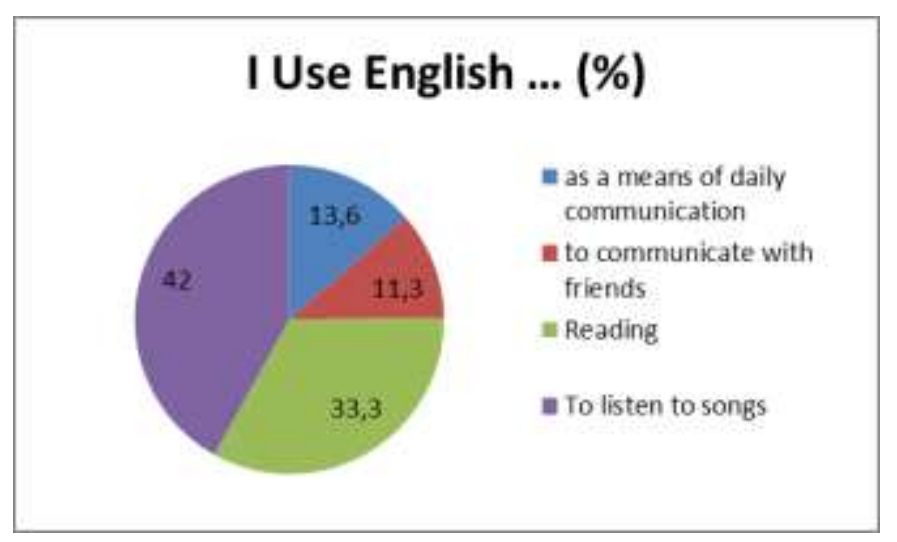

Figure 3. The Students' Trending Use of English

Figure 3. portrays the students' current choices in what English is used to. $42 \%$ of all choice is addressed to using English to listen to songs followed by using English for reading materials which takes 33.3 percent. Further, $13.6 \%$ choice is addressed to using English as a means of daily communication, and only $11.3 \%$ of total choices is addressed to using English to communicate with friends. It concludes that most of the students are not an active English speaker because most of them use English for listening to songs and reading. 


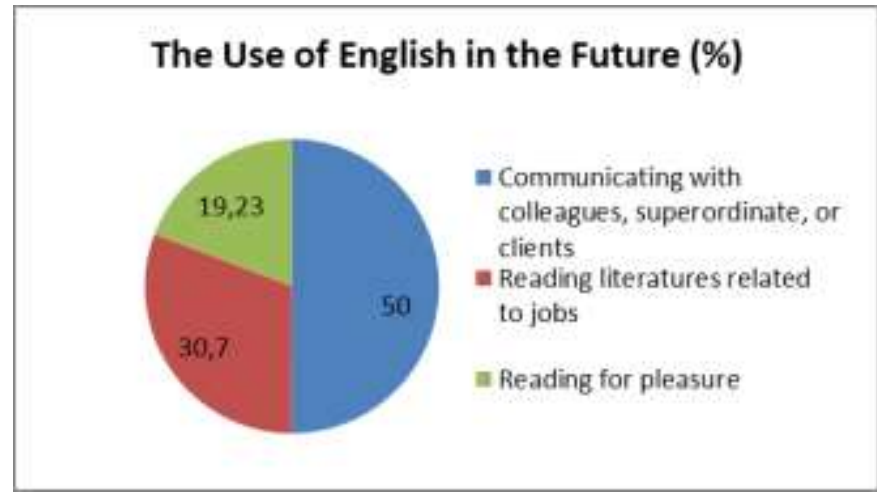

Figure 4. The Students' Perception of the Use of English in the Future

Figure 4. shows the percentage of students' opinion on the use of English in the future which indicates their perception about its significance in the future. The chart shows half of the choice is addressed to communicating with colleagues, superordinate, and or clients. It means half of the students believe mastering English is very important to support their career in the future. On the other hand, $30.7 \%$ of the total choices is addressed to reading literatures related to jobs. It means they are aware that many books use English as the language of communication, prominently those imported from overseas. Accordingly, they see this very important to be able to understand English content from reading books. In the last position, reading for pleasure is chosen by $19.23 \%$ of the total choices

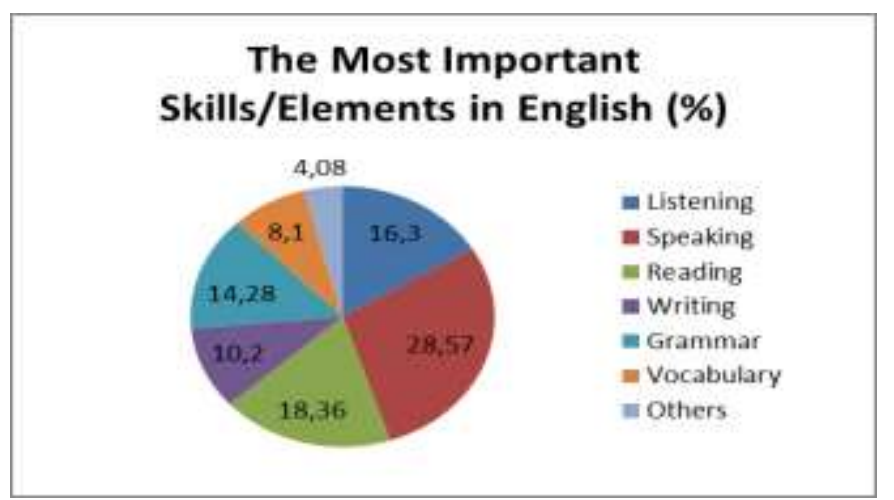

Figure 5. The Students' Choices on the Most Important Skills/Elements in English

Figure 5. portrays percentage of the students' priority in mastering language skills and elements. It is shown that speaking skill takes the highest percentage $(28.57 \%)$. It is worth noting that learning materials should include speaking activities to accommodate the students' demand. The second highest percentage is reading skill which, to many students are considered important to improve. The following skill is listening skill with $16.3 \%$, and grammar for $14.28 \%$. While writing skill was chosen for $10.2 \%$, and vocabulary was for $8.1 \%$. The number of percentage of one skill is not hugely dominant to other skills. It shows that there is no one skill which is absolute to be focused on than other skills in comparison. It concludes that listening skills and elements should be considered equal and integrated instead of partial. 


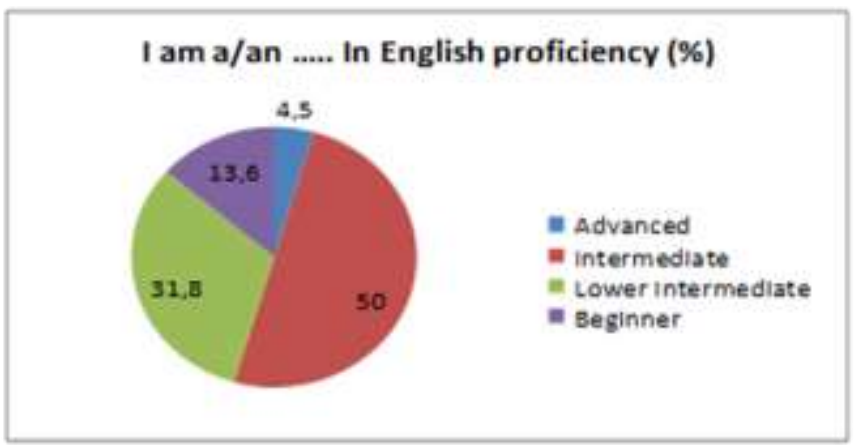

Figure 6. The Students' Choices on Their Own English Proficiency Level

Figure 6. shows the percentage of English proficiency level of the students based on their self-assessment. they were given four stratified levels to choose in which level they belong to subjectively. It was found that $50 \%$ of them think they are intermediate in English. It means they think they are able to communicate in both oral and written form even though not fluent yet. 31.8 of them, on the other hand, think they belong to lower intermediate in English. It means they think they are able to comprehend what people say or what they read, but they cannot give proper response. $13.6 \%$ of the students think they are at beginner level which means they lack of exposure to English. $4.5 \%$ of the students think they are at advanced level which means they can communicate in every context fluently.

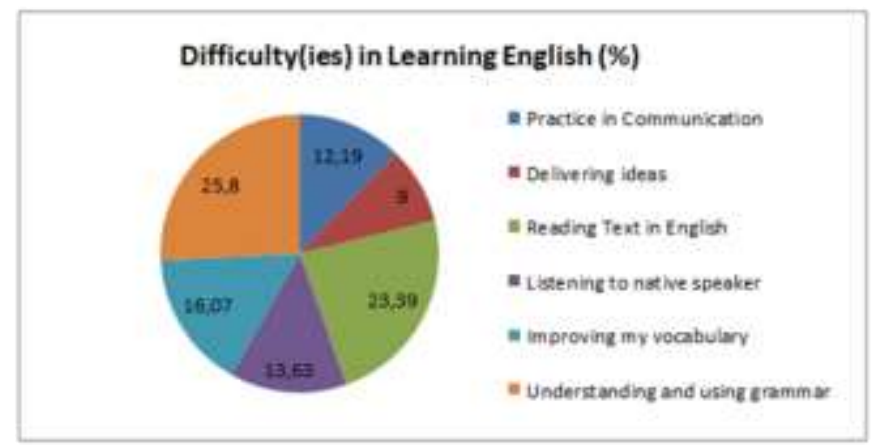

Figure 7. The Students' Difficulties in Learning English

Based on Figure 7., it is found that some difficulties the students face in learning English are understanding and using grammar for $25.8 \%$, reading text $(23.39 \%)$, improving vocabulary for
$16.07 \%$, listening to native speaker for $13.63 \%$, practice in communication for $12.19 \%$, and delivering ideas for $9 \%$. 


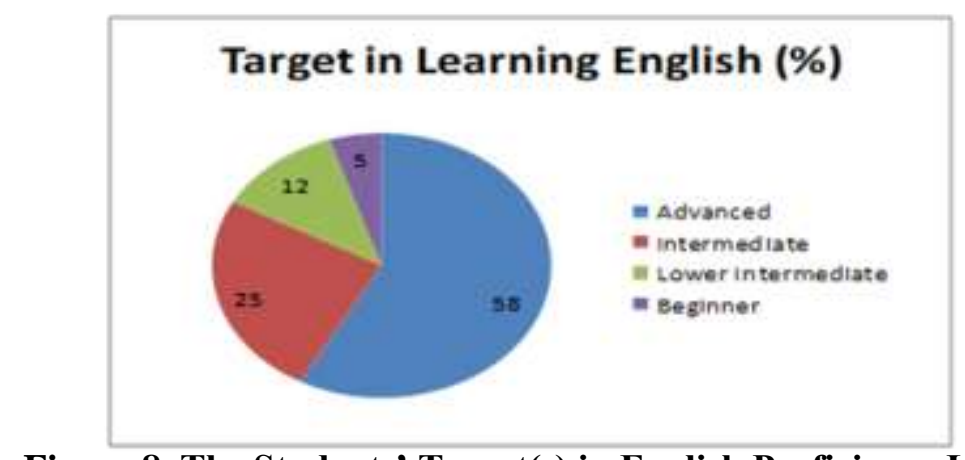

\section{Figure 8. The Students' Target(s) in English Proficiency Level}

Another item asks the students' target to reach after learning English as shown by figure 8 . It was found that $58 \%$ of the students hope to be advanced learner as they want to be able to communicate fluently. $25 \%$ of them hope they want to reach intermediate level in English. While $12 \%$ of the students hope to reach lower intermediate level and just 5\% of them were pessimistic that it does not matter to just remain a beginner.

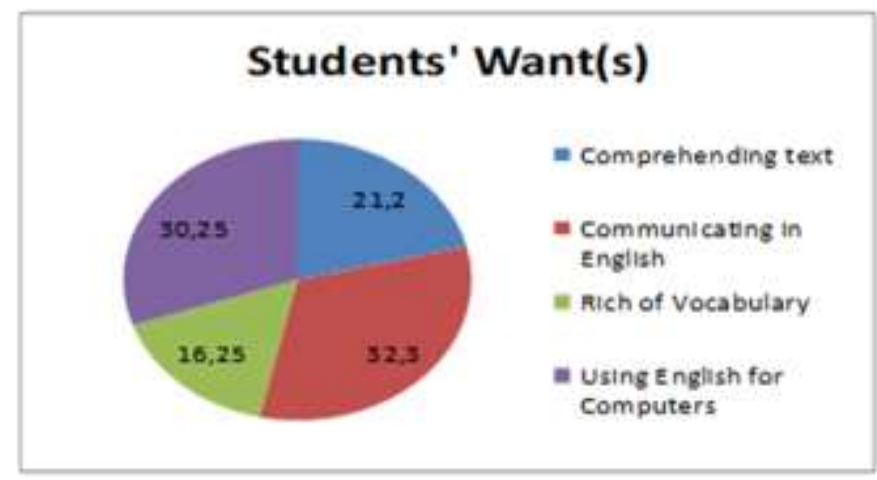

Figure 9. The Students' Wants

Figure 9. shows students' wants in learning English. Specifically, the figure shows what materials they hope to be learned in the module. The answers to this item is varied that not even one choice dominates over the others. $32.5 \%$ of the students want materials that improve their communication skill. $30.25 \%$ choice is addressed to learning English about computers. $21.2 \%$ of the students choose materials that improve their reading comprehension, and $16.25 \%$ of the students want to learn vocabulary in many sessions. 


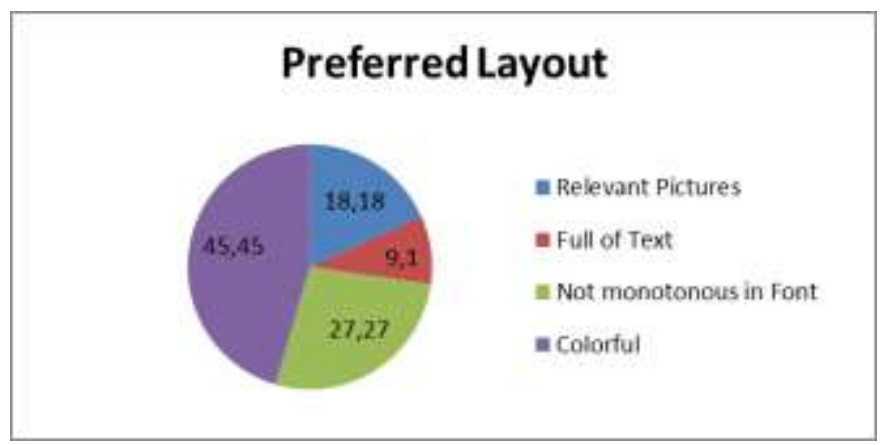

Figure 10. Preferred Layout

The students were also questioned about module layout they prefer. Figure 10. shows that $45.45 \%$ of the choices were addressed to colorful layout followed by layout with not monotonous font for $27.27 \%$. $18.18 \%$ of the choice is, on the other hand, to layout with relevant pictures, and $9.1 \%$ of the choices is layout with full of text.

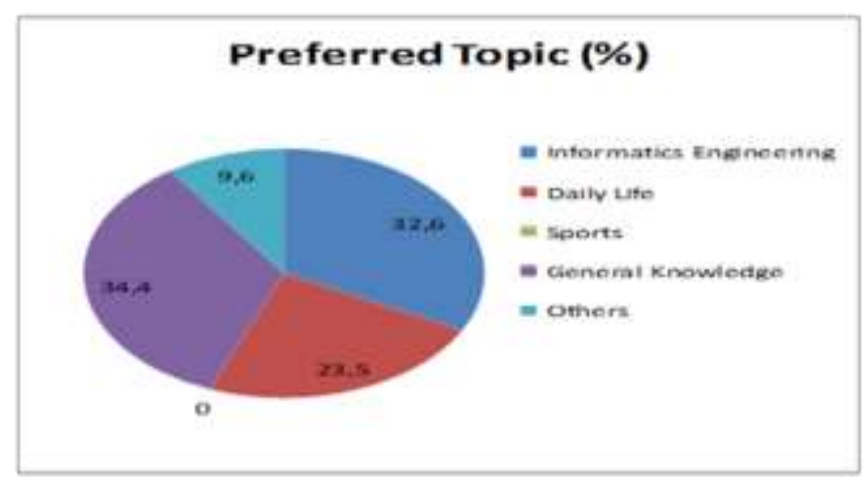

Figure 11. The Students' Preferred Topic

The students were also questioned about what topic they want to learn more. Is it about general knowledge, computer matters, sports, daily life topics, or other topics? Figure 11. Shows that $34.4 \%$ of the choices is topics related with general knowledge followed by topics about informatics engineering for $32.6 \%$. Then, $23.5 \%$ requested topics about daily life, and $9.6 \%$ choose to learn about other topics. No one choose irrelevant topic like sports. 


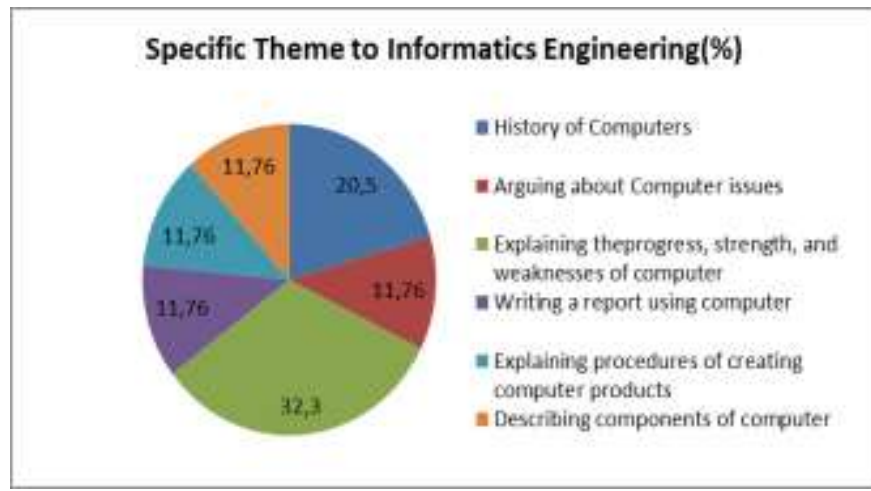

Figure 12. The Students' Preference to Themes of English for Informatics Engineering

The last item addressed to the students is, for they are informatics Engineering students, what computer-related topics they want to learn. $32.3 \%$ of the students requested to learn about how to explain the progress, strength, and weaknesses of computers today. $20.5 \%$ of the students requested to learn the history of

\section{DISCUSSION}

\section{A. The Students' Necessities}

To conclude the students' necessities in learning English, four items were given. They are (1) goal(s) in learning English, (2) in what context they use English, (3) the use of English they think is the most beneficial in the future, and (4) skills or elements in English they think is the most important. As seen by Figure 1., 66.33\% is addressed to being fluent in communicating both in oral and written form. This suggests that they realize the urgency of mastering language skills. Being fluent in oral communication means they need to be good at listening and speaking as the lecturer suggested. On the other hand, to have fluent written communication means they must juggle skills in reading and writing. Accordingly, developing the skills through learning activities is demanded so that the students experience them. This is in line with Nishanthi (2018) that in order to succeed the globalization era, students agree that it is compulsory to achieve fluency or mastery over the English language.

Figure 2. shows in what situation they mostly use English. This is to measure their attitude and habitual activities to using English. It informatics engineering, equal percentages $(11.76 \%)$ of the choices requested to learn about describing components of the computers, arguing about computer issues, writing a report using computer, and explaining procedures of creating computer products.

is found that they mostly use English while listening to songs with $42 \%$ followed by reading with $33.3 \%$. It shows that the students are dominant in receptive skills. This finding suggests listening to songs is eligible and reading methods to be taken into consideration as they said they demanded it. This is because songs as a primary channel for learning (Listiyaningsih, 2017) can be used to teach and develop every aspect of a language Džanić (2016).

The third item focuses on to what extent they will find English important to master in the future. $50 \%$ of the students agreed that communicating with colleagues, superordinate, and clients is necessary to have as Nishanthi (2018) is undoubted that English play significant role in the universe to help us in both personal and professional life. To experience so, the students must have learning experience about communication to upper level, the same level, and lower level properly.

Figure 4. shows the percentage of language skills and elements the students prioritize. It is found that the students prioritize speaking skill in the first place followed by 
reading skill in the second place, and listening in the third place. This is admitted by one student that speaking skill is a key to communicating successfully. This finding seems relevant because they will be involved in working filed which needs such skills to survive. Accordingly, without ignoring writing skill in the fourth place, the top three skills must have high attention to be converted to learning activities in the module. This is in line with Nasution (2018) that speaking skill holds significant role to survive living in the $21^{\text {st }}$ century.

\section{B. The Students' Lacks}

The students' lacks are reflected from two questions: (1) finding out what level they think they are in English proficiency, and (2) what difficulties they have in learning English. Figure 5. shows that that the students assessed themselves an intermediate in English for 50\%. While 31.8\% of them think they belong to lower intermediate. The lecturer agreed that most of the students belong to intermediate level based on their score the lecturer documented. It means they need improvement so they can belong to higher level. There must be effective learning strategies to achieve the target since Kunasaraphan (2015) believes learning strategies enable students to improve their limited knowledge and overcome limitations in target language skills. On the other hand, students face difficulties in reading text

\section{CONCLUSION}

Needs analysis functions to give fundamental inputs to developing English materials which are aimed at specific purpose. This has been compulsory for English practitioners to conduct this survey study in order to obtain valuable information from the target to optimize learning outcomes. Overall, it can be concluded that the students are in need of English subject to communicate in both daily conversation and professional field, speaking skill to concern

\section{REFERENCES}

Alsamadani, H. A. (2017). Needs Analysis in ESP Context: Saudi Engineering Students as a
(23.39\%). This is in line with Nurjanah (2018) that students have various challenges in comprehending a text and answering a reading test caused by their level of mastery. Followed by difficulties in using and understanding grammar for $25.8 \%$, and $16.07 \%$ of them find it hard in communication practice as shown by Figure 6. It is concluded that reading activities must be taken into consideration in developing the materials. Accordingly, texts are needed.

\section{The Students' Wants}

The students were also questioned about their wants during and after learning English. Their target after learning English is they want to be advanced in English proficiency level (58\%). As shown by Figure 8. It is supported by a finding from meeting few students that that they all have high expectation to instructional process so it can improve their English proficiency. Further, figure 9 shows skills the students want to have after learning the module. It is found that $32.2 \%$ of them want to be able to communicate. $30.25 \%$ of them think using English for computer operation is also important. This finding is similar with a finding from Hidayati, and Haryati (2018) that a total of 53 students responded to a questionnaire and open-ended interview they conducted and chose fluency in communication as what they want the most.

with more, computer-related material, colorful and interesting layout with relevant pictures. All the mentioned points are beneficial to designing English module for Informatics engineering students at the university. It is proclaimed that this finding is situational, so it is recommended that English lecturers teaching in vocational department conduct the same needs analysis to reveal authentic needs of their students in learning English. 
Astika, G. (1999). The Role of Needs Analysis in English for Specific Purposes. TEFLIN Journal. 10(1). 31-47

Chovancov'a, B. (2014). Needs Analysis and ESP Course Design: Self-Perception Of Language Needs Among Pre-Service Student. CEJSH: The Central European Journal of Social Sciences and Humanities. 38(1). 43-57.

Diana, S., \& Mansur, M. (2018). Need Analysis on English Teaching Materials for ICT Students. ETERNAL: English, Teaching, Learning, and Research Journal. 4(2). 209218.

Džanić, N. D., \& Pejić, A. (2016). The Effect of Using Songs on Young Learners and Their Motivation for Learning English. NETSOL (New Trends in Social and Liberal Science). 1(2). 40-54.

Hattani, H. A. (2019). ESP Needs Analysis at the Moroccan University: Renewable Energy Engineering Students at EST Fes as a Case Study. JELTL (Journal of English Language Teaching and Linguistics). 4(1). 101-115.

Hidayati, D. N,. \& Haryati, S. (2018). Target and Learning Needs in English for Midwifery Students. LEKSEMA: Jurnal Bahasa dan Sastra. 3(1). 71-80.

Hoshangabadwala, A. (2015). Student Perceptions of Textbook Layout and Learnability in Private Schools. Journal of Education and Educational Development. 2(1). 1-16.

Indrasari, N. (2016). English for Specific Purposes: A Need Analysis at The Second Semester of Physics Education Students of IAIN Raden Intan Lampung in The Academic Year of 2015/2016. English Education: Jurnal Tadris Bahasa Inggris. 9(1). 161-172.

Kunasaraphana, K. (2015). English Learning Strategy and Proficiency Level of the First Year Students. Procedia - Social and Behavioral Sciences. Vol. 197. 1853-1858,

Lawson, K.H. (1979). Philosophical Concepts and Values in Adult Education. Milton: Open University Press.
Mayang, A., Nurkamto, J., \& Drajati, N. A. (2019). The Needs Analysis of Senior High School Students' Reading Competence in National Examination: Students' Perspective.. Eternal: English, Teaching, Learning, and Research Journal. 5(1). 130142.

Nasution, S. S. (2016). Model United Nations: Its Effectiveness to Teach Speaking Viewed from the Students' Learning Motivation. Unpublished Thesis. Universitas Sebelas Maret. Surakarta.

Nimasari, E. P. (2018). An ESP Needs Analysis: Addressing the Needs of English for Informatics Engineering. Journal of Educators Society. 3(1). 23-40.

Nishanthi, R. (2018). The Importance of Learning English in Today World. International Journal of Trend in Scientific Research and Development. 3(1). 871-876.

Nunan, D. (2001). Syllabus Design. Oxford: Oxford University Press.

Nurjanah, R. L. (2018). The Analysis on Students' Difficulties in Doing Reading Comprehension Final Test. Metathesis: Journal of English Language Literature and Teaching 2(2). $253-264$.

Pleşca, G. C. (2017). The Role of Needs Analysis in ESP Curriculum Design. https://www.researchgate.net/publication/32 3253882.

Richards, J.C. (2001). Curriculum Development in Language Teaching. UK: Cambridge University Press.

Sukmawati, N. N., \& Nasution, S. S. (2019). Model United Nations: Improving the Students' Speaking Skill. Journal of English Educators Society.4(2). 47-52.

Listiyaningsih, T. (2017). The Influence of Listening English Song to Improve Listening Skill in Listening Class. Academica: Journal of Multidisciplinary Studies. 1(1). 35-49.

Youngshin, S., Youn-Jung, S., \& Doonam, O. (2015). Methodological Issues in Questionnaire Design. J Korean Acad Nurs. 45(3). 323- 328. 